\title{
Effect of some wild egyptian medicinal plants on HAV
}

\author{
Wafaa Kamal Taia ${ }^{1}$, Ahmed Adel Zayed ${ }^{2}$ \\ ${ }^{1}$ Professor of Plant Taxonomy, Department of Botany and Microbiology, Faculty of Science, Alexandria University, \\ Egypt, ${ }^{2}$ Dr. of Medical Sciences, Alexandria University, Egypt
}

Background: Folk Egyptian medicine considered from the most important source of the use of wild plants in medication. Wild plants are considered a perfect source of natural compounds that have been used as antimicrobial andante virus activities. Aims and Objective: The aim of the current study was to investigate the effect of the commonly used wild plants in the treatment of jaundice and they effect on HAV. This article provides much-needed insight into the effect of wild plants on the hepatitis A virus to shed more light on the important subject, which is unfortunately poorly investigated. Materials and Methods: In this investigation, the aqueous plant extracts of twenty-five wild Egyptian species, 16 perennials, and 9 annuals; three concentrations, $1 \%, 3 \%$ \& $5 \%$; were tested for HAV replication by using PA and PCR techniques. Questionnaires and interviews with Bedouins have been carried to know the most used species in the treatment of jaundice, and the usage values were calculated. Those species were collected from their habitats, rare ones purchased and reviewed their identifications and used in this work. Fecal and blood samples were taken from 9-10Y old patients, 35 girls and 25 boys. Results: The PA test revealed that 16 species out of twenty-five gave positive results, while the rest of the species gave negative results on Vero cells. Twelve of the sixteen species were perennial species, and the rest are annuals. The Plaque assay results showed that the most effective aqueous extract species, with the three concentrations, on HAV activity were those of Salvia verbennaca, Mentha microphylla, Ocimum basilicum, Cassia senna, Solenostemma argel, and Thymus capitatus, respectively. PCR test has been carried for the first three species and gave very faint nucleic acid tapes, which means that the plant extract of these species, the three concentrations, minimize the virus activity by a way or another. Samples from the patients tested for the antibodies for $\lg M$ and $\lg$ using the ELISA test. Within both the females $(58 \%)$ and males $(42 \%), 6 \%$ have positive antibodies for $\operatorname{lgM}$, while $36 \%$ in females and $34 \%$ in males' have positive antibodies for IgG and $8 \%$ females and $10 \%$ males have both antibodies (IgM \& IgG). Conclusion: Wild plants, especially those with essential oils can tolerate the Hepatitis $A$ virus (HAV) activity and reduce its symptoms.

Key words: Folk medicine; Hepatitis A virus (HAV); Jaundice; Natural medicine; Wild plants

\section{INTRODUCTION}

The use of wild plants in illness treatments started from the first day of man on Earth. Gradually these plants are categorized according to their uses in scientific orders since Aristotle and his students Theophrastus and Dioscorides and even before that time. The use of plants in medicine is documented in the books 'Medicines of the Egyptians (3000 BC; Pharaohs), the Greeks (400 BC; Hippocrates), and the Romans (37 BC.; Dioscorides)'. In $1982,{ }^{1}$ reported more than 180 phytochemical medicinal compounds could be extracted from wild medicinal plant species. ${ }^{2}$ Reported 200 plant species commonly used in hospitals in illness treatments as traditional medicine. Peoples started using these plants and natural products in the treatment of viral and bacterial diseases 
due to much lower costs and avoid the side effects of chemicals. ${ }^{3,4}$

When we go back in the history of the traditional use of herbal medicine in curing many diseases, we found that the Egyptian and Arabian civilizations, as well as the central Asian ones, were the pioneers in this aspect. ${ }^{5}$ Pharaohs' civilization was from the pioneers in using herbs in medicating illness, dyes, and preparing their tombs. Pharaohs were from the first peoples in the world to use herbal medicine on a rather scientific basis. Their uses of medicinal herbs written in the Ebers Papyrus (c. 1550 BC) include 877 prescriptions on the walls of the temples and found in tombs themselves. ${ }^{6}$ They described and formulated herbal drugs by a specialized priest. ${ }^{7,8}$

Now a day, the world is facing many challenges from the rapidly growing population and deficiency in the required needs to infectious diseases such as hepatitis $A$, $\mathrm{B}$, and $\mathrm{C}$, human immune deficiency, influenza, dengue, and CORONA viruses. Hepatitis A virus is among the pathogens that find their way into the human system through ingestion of contaminated food and an unhygienic lifestyle. Unfortunately, most of the fast foods borne viruses lack licensed antiviral, and most of the Arabic communities get used to eating this unhealthy food. Hepatitis A virus (HAV) is one of the pathogens that find their way into the human system through ingestion of food contaminated with them. This virus infects the livers of the primates only and transfers through the fecal-oral route, ${ }^{9,10}$ found that there is one HAV serotype only, and the body gets immunity after long injection life, ${ }^{11,12}$ found that natural products obtained from plants, animals, and micro-organisms can control and eradicate food-borne viral infections, including hepatitis A.

In this investigation, aqueous solutions of twenty-five wild species, commonly used as herbal medicine in Egypt, tested replication of HAV by using both the Plaque Assay (PA) and Polymerase Chain Reaction (PCR). The aim of this study to know the effect of natural wild plants; used in folk Egyptian medicine; on HAV.

Hepatitis A, first identified in $1973,{ }^{13}$ is a common viral illness across the globe, a highly contagious and short-term liver infection induced by the hepatitis A virus (HAV). The primary route of transmission of hepatitis A is fecal-oral, but close physical contact with the infected individual could also spread the virus.

The main prevention method of hepatitis A is vaccination. The vaccine contains an inactivated virus, and it is considered safe for administration, even in immune compromised individuals. The use of herbal medicine to manage symptoms of viral hepatitis is not uncommon. But, evidence on this matter is limited. Some herbs, such as Salvia verbenaca, have been used in North African and Mediterranean cultures as a food flavoring, but also folk medicine. The herb carries strong antioxidant potential, which could be behind its health benefits. ${ }^{14}$

Besides S. verbenaca, other commonly used herbs for hepatitis A symptoms in folk medicine include spearmint or Mentha microphylla, basil or Ocimum basilicum, Alexandrian senna or Cassia senna, Solenostemma argel, and Mediterranean wild thyme or Thymus capitatus. For example, M. microphylla has anti-infection, anti-flatulence, and anti-inflammatory properties that are believed to stimulate the digestive system in cases of viral hepatitis. ${ }^{15}$ The paper below provides much-needed insight into the effect of wild plants on the hepatitis A virus to shed more light on the important subject, which is unfortunately poorly investigated.

\section{Prevalence of hepatitis A}

On a global scale, millions of people develop HAV infection through the consumption of contaminated water and food. In highly endemic countries, almost all children develop HAV infection at an early age but acquire lifelong immunity. ${ }^{16}$

In Egypt, viral hepatitis is recognized as one of the biggest public health challenges, with eight to 10 million persons or $10 \%$ of the population living with these diseases (WHO). Major causes of viral hepatitis in Egypt are hepatitis $\mathrm{E}$ virus (HEV) and hepatitis A virus. By the age of 15 years, $\geq 50 \%$ of the Egyptian population is exposed to HAV infection. ${ }^{17}$ A prospective cohort study ${ }^{18}$ on 268 Egyptian children found acute HAV infection in 260 children, i.e., $97 \%$ of subjects. Four (1.5\%) cases were relapsing, one case exhibited severe hemolytic anemia, and one case had a cholestatic course. Presentations were generally mild, and subjects achieved recovery within a few weeks, but in endemic areas, an unusual HAV infection pattern is noted.

\section{MATERIALS AND METHODS}

\section{Study area}

Egypt is a country located in the Northeastern corner of Africa, bordered by the Mediterranean and Red seas. The Nile River valley and the Delta are considered the heart of the Egyptian peoples, along with their history. Egyptians were in common touch with the environment and plants, which make them, know how to get used to nature in their living requirements. Interviews with elderly people from different areas and cities in Egypt (Map1) have been carried 
out to know the different plants used, like drinks, in the treatment of jaundice.

This work has been carried out between Oct. 2017 and Dec. 2019. Field trips, ancient reviews of the species used in the treatment of jaundice, as well as Bedouin interviews have been carried out during this period to get information about the most common plant species used as aqueous leaf drinks. This information was mostly from elderly people whose age $>50$ years. Those peoples were from Alexandria, Al-Omayed, Al-Hamam, Borg Al-Arab, Mersa-Matrouh, Suez, Luxor, and Aswan (Map 1). For each plant species, 30-50 people were interviewed, some peoples recommend more than one sp., with an overall opinion reach 100 shares for all the studied species. Unreliable opinions have been discarded. Rare plant species were obtained from the herbal shops and examined carefully to be sure of their identity. The usage value of the plant species has been calculated by dividing the number of peoples used that species by the total numbers of peoples in the questionnaire. The taxonomic determination of the material was carried out accordingly. ${ }^{19,20}$ List of the plants' information used in this investigation is shown in Table 1.

\section{Plant materials}

The plants' species were collected from the different locations in Egypt as illustrated in Map 1; rare species bought from the shops and confirmed their identifications using. ${ }^{20}$ The shoot system was dried in an oven at $45-50^{\circ} \mathrm{C}$ for $12 \mathrm{~h}$, then ground to a fine powder and stored in plastic vials.

\section{Preparation of the aqueous extract}

In $100 \mathrm{ml}$ of distilled water at $60^{\circ} \mathrm{C}$, five grams of the stock powder plants leaves were extracted for $24 \mathrm{~h}$. Then, they were centrifuged for $15 \mathrm{~min}$ at $3000 \mathrm{rpm}$ and evaporated to near dryness. To obtain a stock solution, the resulting viscous powder was dissolved. $1 \%, 3 \%$, and $5 \%$ solutions were prepared from each plant species to investigate their effects on HAV.

\section{Indicator used}

Enzyme volumetric indicator, Enzyme-Linked Immune Sorbent Assay (ELIZA) used Immunoglobulin M ( $\operatorname{IgM})$ and Immunoglobulin C (IGC) techniques as mentioned. ${ }^{21}$

\section{Choosing the HAV strain}

The strain of the virus is HAV-H10, isolated from infected fecal samples of patients between 6 and 10 years old were chosen during the studied period from El-Merry hospital in Alexandria, Egypt (Table 2). The samples were stored in a deep freezer at $-20^{\circ} \mathrm{Cfor}$ further use. Ten-fold dilutions of the virus were prepared by taking $0.9 \mathrm{ml}$ Phosphate Base Solution (PBS) and add $1 \mathrm{ml}$ Virus Neat to prepare the first dilution $10^{-1}$, then take $1 \mathrm{ml}$ of the first dilution in another tube and complete it with $9 \mathrm{ml}$ PBS to prepare the second dilution and so on till the $10^{\text {th }}$ dilution.

\section{Cell cultures}

Vero cells obtained from the Green Monkey Kidney obtained from the cell culture unit in King Fahd for medical research, Jeddah. Vero cells are the most appropriate type for viral replication, as mentioned. ${ }^{22}$ The Vero cells have been grown in Minimum Essential Medium Eagle (MEME) culture media with 10\% Fetal Calf Serum (FCS) and incubated in the incubator with $5 \% \mathrm{CO}_{2}$ and $95 \%$ relative humidity at $37^{\circ} \mathrm{C}$ for 24 hours.

\section{Plaque assay technique}

Techniques used to know the number of viral molecules capable of infect Vero cells after dissolving them by trypsin enzyme for three minutes and then add Fetal Calf Serum (FCS) to stop the action of the trypsin enzyme. ${ }^{23}$ Each $5 \mathrm{ml}$. of the MEME media with $10 \%$ FCS was poured in Petri dishes and incubated at $37^{\circ} \mathrm{C}$ for 24 hours. Then the media decanted, leaving the adhered cells in the Petri dishes. The design of the Plaque essay experiment is shown in Table 3.

These Petri dishes have been incubated at $37^{\circ} \mathrm{C}$ and examined daily to observe the infected cells using an inverted microscope.

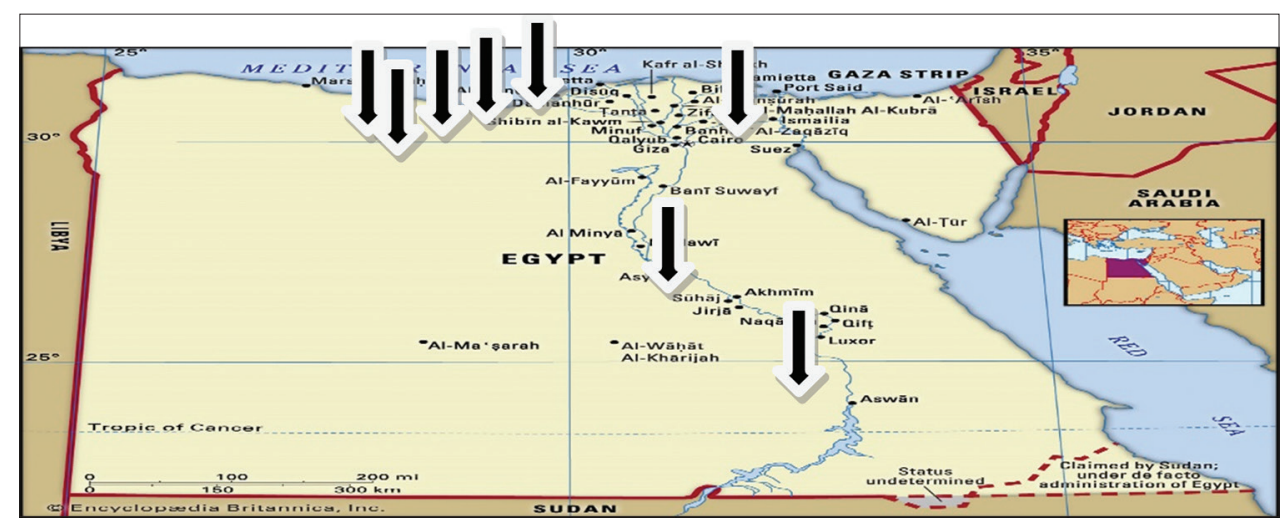

Map 1: Showing the locations of the wild species and peoples in the questionnaire 


\begin{tabular}{|c|c|c|c|c|c|c|c|c|c|}
\hline No. & $\begin{array}{l}\text { Sub- } \\
\text { Class }\end{array}$ & Order & Family & Species & $\begin{array}{l}\text { Vernacular } \\
\text { name }\end{array}$ & Engl. name & Life span & Effect & UV \\
\hline 1 & $\begin{array}{l}\text { Archichla- } \\
\text { medeae }\end{array}$ & $\begin{array}{l}\text { Polygo- } \\
\text { nales }\end{array}$ & Polygonaceae & $\begin{array}{l}\text { Calligonum } \\
\text { comosum L. }\end{array}$ & Ern & Caligonum & Perennial & $+\mathrm{ve}$ & 0.56 \\
\hline 2 & & & & $\begin{array}{l}\text { Rumex nervosus } \\
\text { Vahl }\end{array}$ & Anzab & Sorrels & Annual & $-v e$ & 0.26 \\
\hline 3 & & $\begin{array}{l}\text { Caryophy- } \\
\text { llales }\end{array}$ & Portulaca-ceae & $\begin{array}{l}\text { Portulaca oleracea } \\
\text { L. }\end{array}$ & Regla & Duck weed & Annual & +ve & 0.64 \\
\hline 4 & & & Caryophyllaceae & Silene nocturna L. & Silene & Catchyfly & Annual & $+v e$ & 0.63 \\
\hline 5 & & & Amarantha-ceae & $\begin{array}{l}\text { Aerva javanica } \\
\text { (Burm. F.) Merrill }\end{array}$ & Taref & kapok bush & Perennial & $-v e$ & 0.28 \\
\hline 6 & & $\begin{array}{l}\text { Papave- } \\
\text { rales }\end{array}$ & Capparaceae & $\begin{array}{l}\text { Capparis } \\
\text { aegyptiaca Lam, }\end{array}$ & $\begin{array}{l}\text { Ward } \\
\text { El-Gabal, } \\
\text { Shoak el } \\
\text { homaar }\end{array}$ & Desert date & Perennial & $+\mathrm{ve}$ & 0.76 \\
\hline 7 & & & Cleomaceae & $\begin{array}{l}\text { Cleome } \\
\text { chrysantha Decne }\end{array}$ & Klayom & $\begin{array}{l}\text { Spider } \\
\text { flower }\end{array}$ & Annual & $+\mathrm{ve}$ & 0.92 \\
\hline 8 & & & Brassicaceae & $\begin{array}{l}\text { Anastatica } \\
\text { hierochuntica L. }\end{array}$ & Kaf Marium & Anastatica & Annual & $-v e$ & 0.23 \\
\hline 9 & & & Resedaceae & $\begin{array}{l}\text { Oligomeris linifolia } \\
\text { (Vahl) Macbr. }\end{array}$ & Denbat & Lineleaf & Annual & $-v e$ & 0.42 \\
\hline 10 & & Rosales & $\begin{array}{l}\text { Fabaceae } \\
\text { Subfamily }\end{array}$ & $\begin{array}{l}\text { Alhagi maurorum } \\
\text { Medic }\end{array}$ & Akool & Camelthorn & Perennial & $-v e$ & 0.33 \\
\hline 11 & & & papillionoi-deae & $\begin{array}{l}\text { Lygos raetam } \\
\text { (Forssk.) Heywood }\end{array}$ & Lygos & White broom & Perennial & $-v e$ & 0.26 \\
\hline 12 & & & & $\begin{array}{l}\text { Medicago } \\
\text { orbicularis (L.) } \\
\text { Bartal }\end{array}$ & Hassak & $\begin{array}{l}\text { Button } \\
\text { clover }\end{array}$ & annual & $+\mathrm{ve}$ & 0.83 \\
\hline 13 & & & & $\begin{array}{l}\text { Tephrosia } \\
\text { quartiniana Cuf. }\end{array}$ & Tephrosia & Fish poison & Perennial & $+\mathrm{ve}$ & 0.76 \\
\hline 14 & & & $\begin{array}{l}\text { Fabaceae } \\
\text { subfamily } \\
\text { Cercideae }\end{array}$ & Cassia senna L. & Sennamiky & Senna & Perennial & $+\mathrm{ve}$ & 0.96 \\
\hline 15 & & $\begin{array}{l}\text { Gerania- } \\
\text { les }\end{array}$ & Zygophylla-ceae & $\begin{array}{l}\text { Fagonia bruguieri } \\
\text { DC }\end{array}$ & Fagonia & Fagonia & Perennial & +ve & 0.76 \\
\hline 16 & & & & $\begin{array}{l}\text { Tribulus terrestris } \\
\mathrm{L} \text {. }\end{array}$ & Sharshar & Caltrop & Annual & $-v e$ & 0.22 \\
\hline 17 & & & Euphorbia-ceae & $\begin{array}{l}\text { Chrozophora } \\
\text { oblique (Vahl) } \\
\text { A.Juss.ex Spreng }\end{array}$ & Ketr & Turnsole & Perennial & $-v e$ & 0.22 \\
\hline 18 & & Malvales & Malvaceae & $\begin{array}{l}\text { Hibiscus } \\
\text { micranthus L.f. }\end{array}$ & $\begin{array}{l}\text { Khassia } \\
\text { Rasheed }\end{array}$ & $\begin{array}{l}\text { Tinny flower } \\
\text { Hibiscus }\end{array}$ & Perennial & +ve & 0.75 \\
\hline 19 & $\begin{array}{l}\text { Sympeta- } \\
\text { leae }\end{array}$ & $\begin{array}{l}\text { Gentian- } \\
\text { ales }\end{array}$ & Asclepiada-ceae & $\begin{array}{l}\text { Solenostemma } \\
\text { argel (Del.) Hayne }\end{array}$ & Hargel & Argel & Perennial & +ve & 0.95 \\
\hline 20 & & Tubiflorae & Lamiaceae & $\begin{array}{l}\text { Mentha } \\
\text { microphylla } \\
\text { C.Koch }\end{array}$ & Neenaa & Spear, mint & Perennial & $+v e$ & 0.99 \\
\hline 21 & & & & $\begin{array}{l}\text { Ocimum basillicum } \\
\text { L. }\end{array}$ & Rehan & Basil & Perennial & +ve & 0.98 \\
\hline 22 & & & & $\begin{array}{l}\text { Salvia verbenaca } \\
\text { L. }\end{array}$ & Maramia & Wild sage & Perennial & $+v e$ & 0,99 \\
\hline 23 & & & & $\begin{array}{l}\text { Thymus capitatus } \\
\text { (L.) Hoffmgg. }\end{array}$ & Zaatr & $\begin{array}{l}\text { Conehead } \\
\text { thyme }\end{array}$ & Perennial & $+\mathrm{ve}$ & 0.95 \\
\hline 24 & & & Solanaceae & $\begin{array}{l}\text { Withania } \\
\text { somnifera (L.) } \\
\text { Dun. }\end{array}$ & Sakran & $\begin{array}{l}\text { Winter } \\
\text { cherry }\end{array}$ & Perennial & -ve & 0.22 \\
\hline 25 & & & Scrophulariaceae & $\begin{array}{l}\text { Bacopa monieri } \\
\text { (L.) Pennell }\end{array}$ & Wetwat & $\begin{array}{l}\text { Water } \\
\text { hyssop }\end{array}$ & perennial & +ve & 0.67 \\
\hline
\end{tabular}

\section{Enzyme-Linked ImmunoSorbent Assay (ELISA)}

This technique is an immunological assay commonly used to measure antibodies, antigens, proteins, and glycoproteins. The technique used is that of ${ }^{24}$ on the viral strain $(+v e)$, Dist. Water + virus (-ve), sixteen +ve HAV antibodies IgM type, and sixteen aqueous plant species extracts, which indicate negative viral replication effect in Vero culture cells. The viral RNA has been 


\begin{tabular}{|c|c|c|c|c|}
\hline Sex & IgM only & IgG only & $\lg M \& \lg G$ & Total \\
\hline Female & 4 & 25 & 6 & 35 \\
\hline Males & 3 & 17 & 5 & 25 \\
\hline
\end{tabular}

Table 3: The Plaque essay experiment

\begin{tabular}{ll} 
Blank & Treatments for each species \\
\hline 1-Cell culture Petri dish only. & - \\
2- Cell culture Petri dish $+1 \mathrm{ml}$ & Cell culture Petri dish $+1 \mathrm{ml} 5 \%$ \\
$5 \%$ plant extract. & plant extract $+1 \mathrm{ml}$ viral extract. \\
3- Cell culture Petri dish $+1 \mathrm{ml}$ & Cell culture Petri dish+1ml $3 \%$ \\
$3 \%$ plant extract. & plant extract $+1 \mathrm{ml}$ viral extract. \\
4- Cell culture Petri dish $+1 \mathrm{ml}$ & Cell culture Petri dish $+1 \mathrm{ml} 1 \%$ \\
1\% plant extract. & plant extract $+1 \mathrm{ml}$ viral extract. \\
$5-$ Cell culture Petri dish $+1 \mathrm{ml}$ & - \\
viral extract. &
\end{tabular}

extracted by adding $25 \mathrm{ml}$ Extrazol $+25 \mathrm{ml}$ Phenol $+2.5 \mathrm{ml}$ Sodium acetate. Then the viral RNA in the extracted solution has been transformed to DNA using Reverse Transcriptase Kit (RT) and put in the Thermal Cycler for 90 minutes at $37^{\circ} \mathrm{C}$ and for one minute at $95^{\circ} \mathrm{C}$ for the Denaturation, then at $60^{\circ} \mathrm{C}$ for another minute for Annealing, and another minute at $72^{\circ} \mathrm{C}$ for Extension. This cycle can be repeated 35 times and by the end, keep the tubes at $72^{\circ} \mathrm{C}$ for 5 minutes for Final extension. ${ }^{25}$ This technique used by the aid of the calibration indicators from the Italian Dia Sorne company Elisa Commandet Instrument. ELISA is a method of target antigen (or antibody) capture in samples using a specific antibody, and of target molecule detection/quantitation using an enzyme reaction with its substrate. enzyme activity was measured by colorimeter.

\section{Primer used}

CE (+), CE: general primer 5`ATTGGATTGG CCATCCGGTG3

$\mathrm{H}(-)$, H: primers of HAV5 ${ }^{`}$ CCAATCTTCC TGATCCAAAGC3

$\mathrm{H}(+) 1, \mathrm{H}$ : primers of HAV5 ${ }^{`}$ AACCCTACAC CTTTCCAACA3

$\mathrm{H}(+) 2, \mathrm{H}$ : primers of HAV5 ' GATTCATTCT GCAGAT'TGGC3`

\section{RESULTS}

The injection of the three concentrations (1\%,3\% and 5\%) of the twenty-five aqueous plant species extracts in Vero cells with the HAV showed that sixteen (16) species of them have + ve results (Table 1). These species are Calligonum comosum, Portulacca oleracea, Silene nocturna, Capparis egyptiaca, Cleome chrysantha, Medicago orbicularis, Tephrosia quartiniana, Cassia senna, Fagonia bruguiri, Hibiscus micranthus, Solenostemma hargel, Mintha microphylla, Ocimum basillicum, Salvia verbenaca, Thymus capitata, and Bacopa monieri. These species are belonging to different families, as shown in Table 1. These species showed inhibition effects on the viral activity without harming the host cells in the three concentrations used. This means that these species have neither poisonous nor harmful elements and are considered safe in use. The rest of the studied species, nine species, showed the toxic effect to Vero cells which appeared circular and smaller and floated in the culture media. This means that these species have either toxic or harmful elements. The perennial species were the most active ones as $12 \mathrm{sp}$. Out of 16 gave + ve result, while the annual species were moderate in their activity (Figure 1).

The Plaque assay results (Figure 2) showed that the most effective aqueous extract species on HAV activity were those of Salvia verbennaca, Mentha microphylla, Ocimum basilicum, Cassia senna, Solenostemma argel, and Thymus capitatus, respectively, as shown by the color intensity.

The Polymerase Chain Reaction (PCR) for the three species, Mentha microphylla, Ocimum basillicum, and Salvia verbenaca, revealed that the Vero cells injected by HAV-H10 and the aqueous plant extract showed very faint nucleic acid tapes, which means that the plant extract of these species, the three concentrations, minimize the virus activity by a way or another (Figure 3).

The result of the selected random samples of the patients' ages from 6 to 10 years old was 35 female and 25 male blood samples (Table 1). These samples have been tested for the antibodies foran IgM and IgG using ELISA test (Table 1). Within both the females (58\%) and males (42\%), 6\% have +ve antibodies for $\mathrm{IgM}$ which means that those peoples have active viral infection, while $36 \%$ in females and $34 \%$ in males' have +ve antibodies for IgG, which mean that HAV has been previously infected those peoples and they recovered and gave them total immunity. $8 \%$ females and $10 \%$ males have both antibodies ( $\operatorname{IgM}$ and $\operatorname{IgG}$ ), which means that the virus is active in spite of the previous infection (Figure 4).

\section{DISCUSSION}

The liver considered the large glandular vital organ in the human body responsible for the metabolism of food, excretion of waste metabolites and chemicals from the body ad protect the body from foreign substances. Though, protection of this gland is an essential aim to stabilize the body functions. ${ }^{26}$ Gave the reasons for the acute liver diseases, which are called Hepatitis $(\mathrm{H})$. Hepatitis is a condition characterized by the destruction of liver cells 


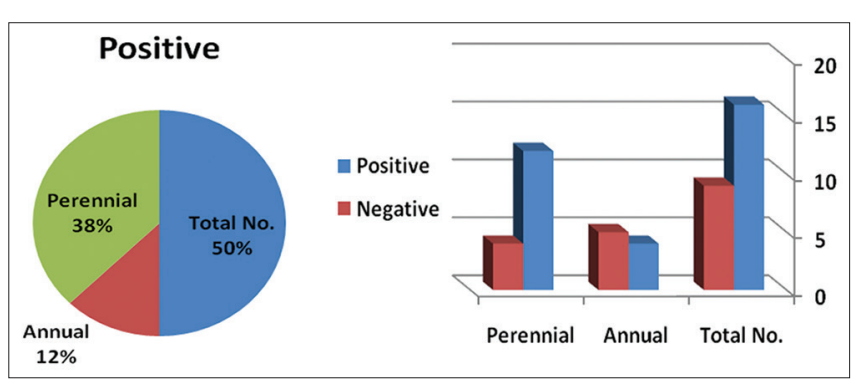

\begin{tabular}{lcc} 
& Positive & Negative \\
\hline Total No. & 16 & 9 \\
Annual & 4 & 5 \\
Perennial & 12 & 4 \\
\hline
\end{tabular}

Figure 1: Number of both perenniual and annual species used and the relation between the +ve and -ve results obtained in both life forms

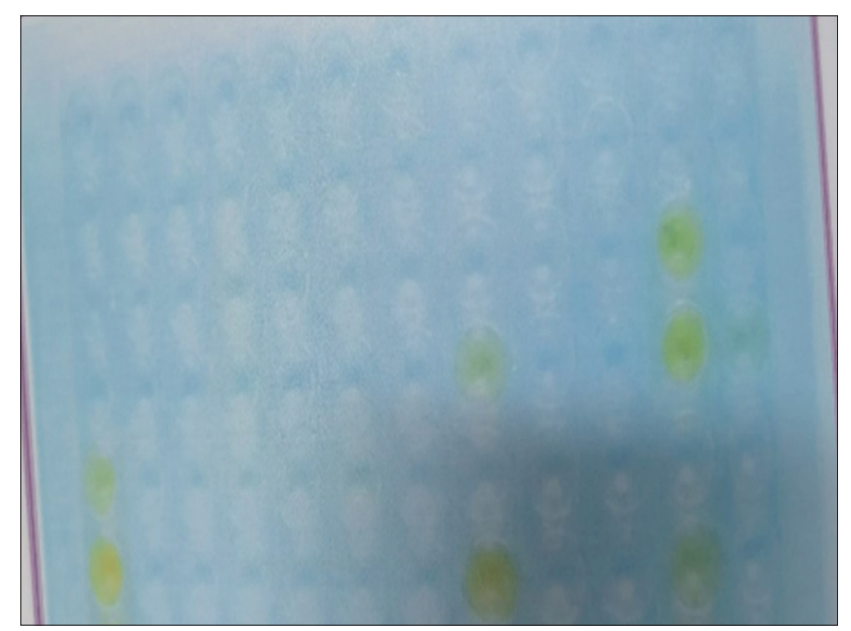

Figure: 2 PA results

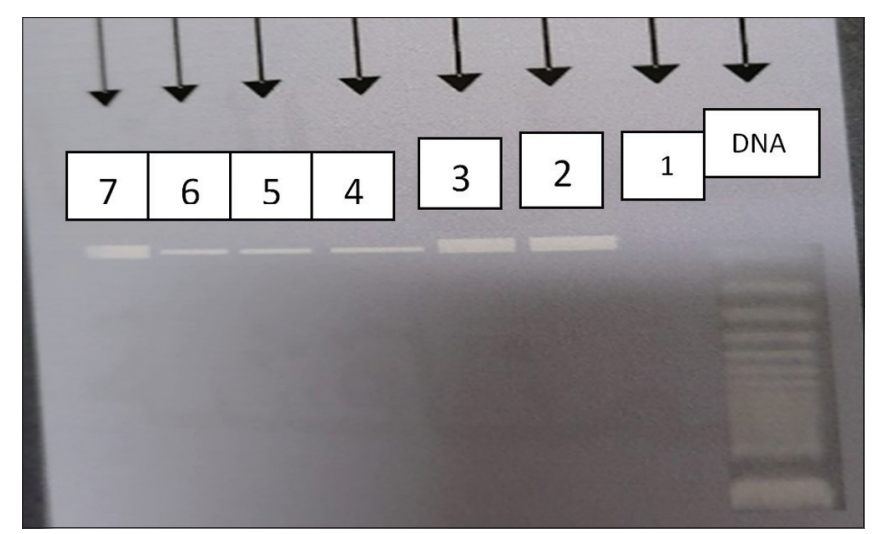

Figure 3: PCR result

$1=-$ ve Blanc, $2=+$ ve, 3=HAV, 4=HAV+ Mentha, 5=HAV+Ocimum, $6=\mathrm{HAV}+$ Salvia, $7=+$ ve Serum+IGM

and the inflammation of cells in the liver tissues), and subsequently, jaundice. There are many Viruses causing different types of H. such as Hepatitis A, B, C, D, and E, besides mononucleosis caused by cytomegalovirus. The use of wild plants in the treatment of many illnesses started from the earliest history of man on the land. The Egyptians were the pioneer in this aspect, especially the Pharaohs, and till now, the Egyptian Bedouins used some plants in their treatments and considered those plants are most useful than tablets. ${ }^{27}$ Found that the aqueous extract of three wild Egyptian plant species can be used as antifungal and anti-toxigenic. The use of herbal medicines for the treatment of viral hepatitis is based on the belief these plants or compounds are safe and effective. Herbal drugs have become popular in Egypt to avoid the side effects of tablets and are considered as a cheaper way in treatments, and their use is widespread. ${ }^{28}$ Warned of the low efficiency of antiviral therapies due to the counter-production of viral mutants and the costs of the vaccines, which make it difficult for poor countries. Herbal medicines have been used in the treatment of liver diseases for a long time all over the world, especially in developing countries. ${ }^{29}$

This study carried mainly on HAV extracted from children aged from 6 to 10 years old fecal samples. In Egypt HAV is wide spread among children as mentioned. ${ }^{17}$ The results obtained revealed that sixteen plant species out of twenty-five have an inhibition effect on HAV (Table 3), i.e. $64 \%$ of the studied species. Most of the + ve species are perennials. This result can be explained by one of two reasons, either these plants have a protective ability to the host cells that inhibit its adherence, or they have an inhibitory effect on the virus itself by covering its receptor surfaces or changing the $\mathrm{pH}$ degree of the media. The most used plant species, UV more than $90 \%$ are Cleome chrysantha, Cassia senna, and those belonging to the families Asclepiadaceae and Lamiaceae. Those species are used as herbal medicine in the treatments of many diseases in Egypt. In the same time ${ }^{14}$ pointed to the potential use of these species as antiviral. Those species characterized by the high contents of Essential Oils (EOs), which have a high value in medicinal properties. ${ }^{29}$ Meanwhile, these species have been reported as antiviral plants due to their high contents in the Eos and other constituents, which give them potential inhibition against viral replication. ${ }^{30}$ Family Lamiaceae is the most effective family in the treatment of $\mathrm{HAV}$; species belonging to this family characterized by the presence of volatile oils, and these oils are used in the treatment of many diseases since a long time ago and till now, ${ }^{31}$ found that the volatile oils in Eucalyptus species can be used as antibacterial, antioxidant, and antiproliferative activities. They reported the importance of these species, with high contents of volatile oils, in supporting the body's immune system. This can clarify the result obtained in this investigation, ${ }^{32}$ confirmed that the green tea has antiviral effect. These observations indicate that herbs can be used in the treatment of much disease.

The ELISA test for the blood samples of the patients; females (58\%) and males (42\%); revealed that the 


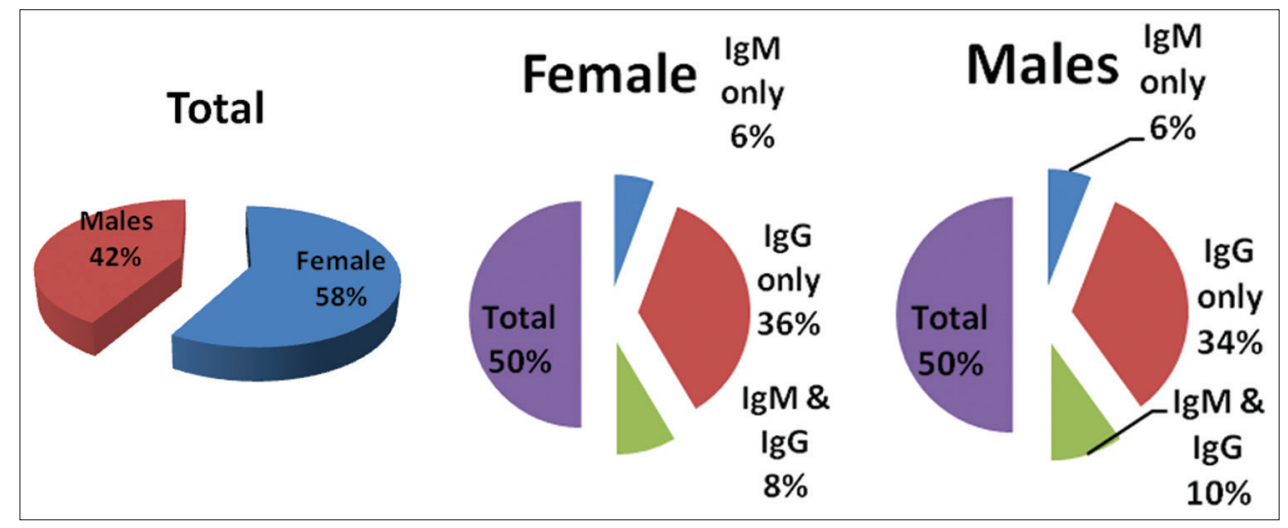

Figure 4: Percentage of females and males, percentage of the antibodies in the blood samples for both females and males

antibodies for IgM and $\operatorname{IgG}$ were $6 \%$ in both females and males have +ve antibodies for IgM which means that those peoples have an active viral infection, while $36 \%$ in females and $34 \%$ in males' have + ve antibodies for $\operatorname{IgG}$ which mean that HAV has been previously infected those peoples and they recovered and gave them total immunity. $8 \%$ of females and 10\% males have both antibodies (IgM and $\operatorname{IgG}$ ), which means that the virus is active in spite of the previous infection.

\section{CONCLUSION}

As reported by the $\mathrm{WHO}$ viral hepatitis is recognized as one of the biggest public health challenges in Egypt, with eight to 10 million persons or $10 \%$ of the population living with these diseases. This investigation has been carried to investigate how much the traditional wild plants can help in the treatment of this virus. Twenty-five wild plant species commonly used in traditional medicine in Egypt subjected in this study. The results obtained revealed that 16 species have a +ve effect on HAV which means that they either support the body immune system or affect the virus activity and multiplication. These most effective species are Salvia verbennaca, Mentha microphylla, Ocimum basilicum, Cassia senna, Solenostemma argel, and Thymus capitatus with more than 95 $\%$ usage value. These species may have protective ability to the host cells that inhibit its adherence, or they have an inhibitory effect on the virus itself by covering its receptor surfaces or changing the $\mathrm{pH}$ degree of the media. This work supports the use of natural plant species, especially those with high content of volatile oil, in supporting the immune system and treatment of some diseases as used in folk medicine.

\section{REFERENCES}

1. ITC. Market for selected medicinal plants and their derivatives. Geneva: International Trade Centre/UNCTAD/GATT; 1982. p. 206.
2. Jarić S, Mačukanović-Jocić M, Djurdjević L, Mitrović M, Kostić O, Karadžić $B$ and Pavlović $P$. An ethnobotanical survey of traditionally used plants on Suva planina moun-tain (south-eastern Serbia). Journal of Ethnopharmacology. 2015; 175: 93-108.

https://doi.org/10.1016/j.jep.2015.09.002

3. Siddiqui MH, Alamri SA, Al-Wahibi MH, Hussain Z, Ali HM and El-Zaidy ME. A mini-review of anti-hepatitis $B$ virus activity of medicinal plants. Biot. and Biot.Equip. 2017; 31 (1): 9-15. https://doi.org/10.1080/13102818.2016.1240593

4. Samani ZN and Kopaei MR. Effective medicinal plants in treating Hepatitis B. IJPSR. 2018; 9(9):3589-3596.

5. Amin A and Mousa M. Merits of anti-cancer plants from the Arabian Gulf region. Cancer Ther. 2007; 5:55-66.

6. Patrick EM, Armen M and Gretchen RH. Ancient Egyptian herbal wines, PNAS website, quoted in the Article "Study: Herbs added to 5,100-year-old Egyptian wine"on the LD News website, accessed 15.April (2009).

7. Haggag MY. Herbal medicine in Egypt. IJPR, Suppl., $2^{\text {nd }}$. Int.Con. Trad.Med. and Mat., 4-7Oct. 2004, Tehran, Iran.

8. Abou El-Soud, NH. Herbal medicine in ancient Egypt. J Med PI Res. 2010; 4(2): 82-86.

9. Balayan MS. Natural hosts of hepatitis A virus. Vaccine.1992; 10 (Suppl 1):S27-S31. https://doi.org/10.1016/0264-410X(92)90537-T

10. Lemon SM, Jansen RW and Brown EA. Genetic, antigenic and biological differences between strains of hepatitis $A$ virus. Vaccine.1992; 10 (Suppl 1):S40-S44. https://doi.org/10.1016/0264-410X(92)90540-Z

11. Lee DY, Chung SJ and Kim KW. Sensory characteristics of different types of commercial soy sauce. Journal of the Korean Society of Food Culture. 2013; 28:640-650. https://doi.org/10.7318/KJFC/2013.28.6.640

12. Lee $M H$, Lee $B-H$, Lee $S$ and Choi $C$. Reduction of hepatitis a virus on frhk-4 cells treated with Korean red ginseng extract and ginsenosides. Journal of Food Science. 2013; 00:M1-M4. https://doi.org/10.1111/1750-3841.12205

13. Ben Farhat M, Chaouch-Hamada R, Sotomayor JA, Landoulsi A and Jordán MJ. Antioxidant properties and evaluation of phytochemical composition of Salvia verbenaca L. extracts at different developmental stages. Plant foods for human nutrition. (Dordrecht, Netherlands) 2015; 70(1): 15-20. https://doi.org/10.1007/s11130-015-0466-9

14. Mamadalieva NZ, Hussain $\mathrm{H}$ and Xiao J. Recent advances in genus Mentha: Phytochemistry, antimicrobial effects, and food applications. Food Frontiers. 2020; 4(1):435-458. 
https://doi.org/10.1002/fft2.53

15. Jefferies M, Rauff B, Rashid H, Lam T and Rafiq S. Update on global epidemiology of viral hepatitis and preventive strategies. World journal of clinical cases. 2018; 6(13): 589-599. https://doi.org/10.12998/wjcc.v6.i13.589

16. Elbahrawy A, Ibrahim MK, Eliwa A, Alboraie M, Madian A and Aly $\mathrm{HH}$. Current situation of viral hepatitis in Egypt. Microbiology and immunology. 2021; 10.1111/1348-0421.12916. Advance online publication.

https://doi.org/10.1111/1348-0421.12916

17. Fouad HM, Reyad, EM and El-Din AG. Acute hepatitis A is the chief etiology of acute hepatitis in Egyptian children: a singlecenter study. European journal of clinical microbiology and infectious diseases: official publication of the European Society of Clinical Microbiology. 2018; 37(10): 1941-1947.

https://doi.org/10.1007/s10096-018-3329-0

18. Ghasemian A. Prevalence of hepatitis A across various countries in the Middle East, African and Eastern European countries. Caspian journal of internal medicine. 2016; 7(4): 302-303.

19. Tackholm V. Students' Flora of Egypt (ed.2) 1976, Cairo University.

20. Boulos, L. Flora of Egypt. Vols.1,2,3. 1999; Al Hadara publishing, Cairo, Egypt.

21. Silberstein E, Xing L, Beek W, Lu J Cheng, H and Kaplan GG. Alteration of Hepatitis A virus (HAV) particles by a soluble food of HAV cellular receptor $1{ }^{\prime}$ containing the immunoglobulin and mucin-like regions. J Virol. 2003; 77(16): 8765-8774. https://doi.org/10.1128/JVI.77.16.8765-8774.2003

22. Kukavica-Ibrulj I, Darveau A and Fliss I. Immunoflorescent detection and quantization of hepatitis $A$ virus in sewage treatment effluent and on agri-food surfaces using scanning co focal microscopy. J Virol Methods. 2003; 108(1): 9-17. https://doi.org/10.1016/S0166-0934(02)00227-6

23. Legeay $\mathrm{O}$, Caudrelier $\mathrm{Y}$, Cordevant $\mathrm{C}$, Rigottier-Gois $\mathrm{L}$ and Lange M. Simplified procedure for detection of enteric pathogenic virus in shell fish by RT-PCR. J Virol Methods. 2000; 90(1): 1-14. https://doi.org/10.1016/S0166-0934(00)00174-9

24. Coelho C, Vinatea CE, Heinert AP, Simoes CM and
Barardi, CR. Comparison between specific and multiplex reverse transcriptase-polymerase chain reaction for detection of hepatitis A virus, poliovirus, and rotavirus in experimentally seeded oysters. Mem Inst Oswaldo Cruz. 2003; 98(4): 465-468. https://doi.org/10.1590/S0074-02762003000400006

25. Anand K and Lal UR. Hepatitis and medicinal plants: An overview. JPP. 2016; 5(6): 408-415.

26. El-Desouki T. Evaluation of effectiveness aqueous extract for some leaves of wild edible plants in Egypt as antifungal and antitoxigenic. Heliyon.2021; 7 e06209: 7 Pp. https://doi.org/10.1016/j.heliyon.2021.e06209

27. Lin L, Hsu W and Lin C. Antiviral natural products and herbal medicines. Journal of Traditional and Complementary Medicine. 2014; 4(1):24-35. https://doi.org/10.4103/2225-4110.124335

28. Swamy MK and Sinniah UR. A comprehensive review on the phytochemical constituents and pharmacological activities of Pogostemon cablin Benth.: an aromatic medicinal plant of industrial importance. Molecules. 2015; 20:8521-8547. https://doi.org/10.3390/molecules20058521

29. Zhang Y, Long Y, Yu S, Li D, Yang M, Guan Y, ET AL. Natural volatile oils derived from herbal medicines: A promising therapy way for treating depressive disorder. Pharmacological Research. 2021; $164: 105376$. https://doi.org/10.1016/j.phrs.2020.105376

30. Miguel MG, Gago C, Antunes MD, Lagoas S, Faleiro ML Megías C, et al. Antibacterial, antioxidant, and antiproliferative activities of Corymbia citriodora and the essential oils of eight Eucalyptus species. Medicines. 2018; 5(3): 61. https://doi.org/10.3390/medicines5030061

31. Peterfalvi A, Miko E, Nagy T, Reger B, Simon D, Miseta A, et al. Much More Than a Pleasant Scent: A Review on Essential Oils Supporting the Immune System. Molecules. 2019; 24(24): 4530. https://doi.org/10.3390/molecules24244530

32. Randazzo W, Falcó-Ferrando I, Aznar R and Sánchez G. Effect of green tea extract on enteric viruses and its application as natural sanitizer. Food Microbiology. 2017; 66:150-156. https://doi.org/10.1016/j.fm.2017.04.018

\section{Author's contribution:}

WKT- Collection, Analysis and Identification of plants and its materials; AAHZ- Explanation of Medicinal importance of plants.

Work attributed to:

Alexandria university.

Orcid ID:

Prof. Wafaa Kamal Taia- (1) https://orcid.org/0000-0003-4581-676X

Source of Funding: None, Conflict of Interest: None. 